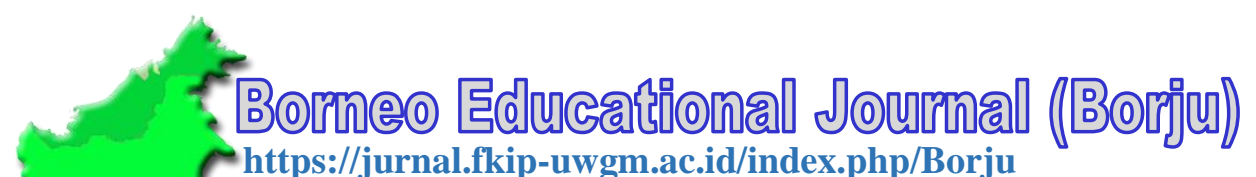

https://jurnal.fkip-uwgm.ac.id/index.php/Borju

E-ISSN: 2655-9323

August 2020, Vol.02 No.02

\title{
Effectiveness of Player Unknown Battleground (PUBG) Video Game in Improving Vocabulary
}

\author{
Sastradwija Putra Perkasa1, Dedi Rahman Nur ${ }^{2}$ \\ Universitas Widya Gama Mahakam, Indonesia ${ }^{1}$ \\ Email Correspondence: sastraputra46@gmail.com
}

\begin{abstract}
One of the online-based games that are popular right now is PUBG. This online-based game is good to be used as an alternative for the student to learn vocabulary. This study aims to compare whether to learn English vocabulary through PUBG online game than pre adopted course. This paper utilized a pre-test and post-test questionnaire to gather the data. There are observations and reactions to digital games. This study indicated that after playing PUBG the students' mean score is significantly higher than before playing the game, showing the beneficial effect of using video games to improve students' English vocabulary. Video games have basic representations of perception that are interactive. Therefore, from an optimistic viewpoint, integrating video games into the learning process must be viewed. It is not a simple task to create video games packed with instructional features, but it is a standard solution to better understand their assignments. Via problem-solving, decision-making, conclusionmaking and collaborative study with their peers, students learn cognitive and beneficial components in addition to fun. Not only do students know about the subject, but they also develop their personalities.
\end{abstract}

Keywords: Video Game; PUBG: Vocabulary

\begin{tabular}{|c|c|c|}
\hline DOI & : & https://doi.org/10.24903/bej.v2i2.629 \\
\hline Received & : & March 2020 \\
\hline Accepted & : & May 2020 \\
\hline Published & : & August 2020 \\
\hline $\begin{array}{l}\text { Copyright and } \\
\text { License }\end{array}$ & : & $\begin{array}{l}\text { Authors retain copyright and grant the journal right of first publication with the } \\
\text { work simultaneously licensed under a Creative Commons Attribution } \mathbf{4 . 0} \\
\text { International License that allows others to share the work with an acknowledgment of } \\
\text { the work's authorship and initial publication in this journal. } \\
\text { cC }\end{array}$ \\
\hline
\end{tabular}




\section{INTRODUCTION}

Vocabulary learning is such a difficult task, so extra efforts are needed to understand, generate and manipulate the target words. Learning vocabulary through games had received enough attention to help and encourages other learners to more quickly understand the target language. Interactive activities can be both fun and informative until games and education fuse together. Students who have learned through games will develop positive attitudes and learn more while they are learning [1]. According to [2] digital games are always succeed tempting students to engage because games are powerful to immerse themselves and involve players. This strength comes from the conception of games containing six fundamental elements: a context, challenge or struggle, goals, rules of engagement, interaction and performance, and immediate feedback. Computer games also enhance user communication and are similar in a working environment, so that users can simulate information exchange and learn from each other. Multiplayer games allow players to participate in teams and to compete with other teams, which help to develop a fair competition between players and their mutual cooperation. Several gameplay aspects are combined and efficiently built for educational games that will inspire players to learn several things. For example, it is used to improve cognitive skill to develop new or existing skills and abilities. In new ways, games can teach old stuff [3].

\section{METHODOLOGY}

This research is conducted using quantitative using experimental research design. Which based on data obtained from students using questionnaires and comparing the effectiveness of its implementation with that of the current course adopted [4]. In this research, the researcher utilized a questionnaire to collect the data for this study. With The population includes 20 College students in Samarinda ranged from 20-25 (male and female) who played the RPG video game (PUBG). The researcher designs one types of questionnaire for each group. The questionnaire consists of 15 questions with 3 indicators adopted from book by [5] and [6]: about vocabulary measurement. To collect the required data, the researcher create a group containing all the participants and give the pre test questionnaire to the participant and then the researcher guide the participant to play the game (PUBG) and asked them several questions about the game how they would address certain questions about how they play the game, what vocabulary they would learn in order to start the game, and how much the game includes them and to what degree it will affect the retention of the vocabulary for 2 weeks. And finally, the researcher give the post test questionnaire to the participants, after all the questionnaire was finished, the researcher compared the responses of the different participants. 
The researcher used descriptive statistics to analyze data that has a goal of evaluating the factors affecting the vocabulary retention of students in learning English by using mean to determine the score. The researcher selected central tendency calculation for analysis of the results.

\section{FINDINGS}

Here, the researcher presented the score of the students' questionnaire score:

Table 1. The mean and standard deviation of the student's vocabulary test

\begin{tabular}{cccccc}
\hline \multicolumn{7}{c}{ Descriptive Statistics } \\
\hline & N & Minimum & Maximum & Mean & Std. Deviation \\
\hline Pre_Test & 20 & 2 & 17 & 9.00 & 3.853 \\
\hline Post_Test & 20 & 6 & 29 & 15.75 & 7.691 \\
\hline Valid N (listwise) & 20 & \multicolumn{7}{c}{} \\
\hline
\end{tabular}

Table 2. F Statistic (ANOVA Result).

\begin{tabular}{|c|c|c|c|c|c|c|}
\hline \multicolumn{7}{|c|}{ ANOVA } \\
\hline & & $\begin{array}{l}\text { Sum of } \\
\text { Squares }\end{array}$ & $\mathrm{df}$ & Mean Square & $\mathrm{F}$ & Sig. \\
\hline \multirow[t]{3}{*}{ Pre_Test } & Between Groups & 1.800 & 1 & 1.800 & .116 & \\
\hline & Within Groups & 280.200 & 18 & 15.567 & & \\
\hline & Total & 282.000 & 19 & & & \\
\hline \multirow[t]{3}{*}{ Post_Test } & Between Groups & 36.450 & 1 & 36.450 & .603 & .447 \\
\hline & Within Groups & 1087.300 & 18 & 60.406 & & \\
\hline & Total & 1123.750 & 19 & & & \\
\hline
\end{tabular}

From the calculation of ANOVA SPSS the researcher found significant result from the post test showed the result of p-value of 0.447 which is higher than the 0,05 (SPSS standard significance level Tukey) as cited by [7]. This means there is a statistically significant difference level of student's vocabulary improvement after playing PUBG.

\section{DISCUSSION}

Based on the results it can be concluded, that the use of online video game in learning English vocabulary much more successful in collage students. As video games are an important part of the daily life of most students today, and also an important part of our culture as a whole. Research on the use of popular games in education is fairly recent, but increasingly growing. Research is highly concerned with the development of relevant skills and literacies during game play or with the role of games in the forming of learning groups during games or game play relevant [8]. The findings obtained here correlate with what [9] and [10] found. In particular, they interpreted games and online games in general as effective learning aids, resulting in enhanced encouragement of the learners and improved performance during the vocabulary learning process. At the one side, the participants got more involved in Playing and expecting to develop better results, they tried to explore more new words besides a vocabulary prepared for the lesson. The more they acquire the new vocabulary, faster and better they play 
the game. As we can see, video games have a positive effect on the development of students. Usage of these games for students is beneficial for some educational and developmental goals and activities. Yet parents need to be careful about making them less exposed to the negative effects of video games. It is very important to control children's usage of video games. Parents should aware that games can have a powerful impact on kids, and set limits on the amount and quality of games they can play. We can understand the possible benefits in this way while reducing the potential harms.

\section{CONCLUSION}

It can be concluded that video games have beneficial impacts on the learning process. The use of these games in the classroom contributes to greater engagement and promotes children's learning process and academic development. While there is not much scientific research on the use and effectiveness of games in foreign language education, teachers or students give hardly any negative opinions about games either. The learning process is much more pleasurable and the pressures inherent in the learning process are greatly minimized by involving children in these activities. Video games have fundamental immersive representations of cognition. The incorporation of video games into the learning process must therefore be perceived from a constructive perspective. Designing video games filled with instructional features is not a straightforward task but is a popular solution to helping students better comprehend their assignments. In addition to fun, students acquire cognitive and beneficial components by problem-solving, decision-making, conclusions-making and interactive research with their peers. Students not only know about the subject but also develop up their own personalities.

\section{REFERENCES}

[1] V. Donmus, "The use of social networks in educational computer-game based foreign language learning," in Procedia - Social and Behavioral Sciences, 2010, vol. 9, pp. 1497-1503.

[2] M. Prensky, Use their tools! Speak their language. 2004.

[3] M. Prensky, "Fun, Play and Games : What Makes Games Engaging," Scientist, pp. 131, 2013.

[4] D. Chostelidou, "A needs analysis approach to ESP syllabus design in Greek tertiary education: A descriptive account of students' needs," in Procedia - Social and Behavioral Sciences, 2010, vol. 2, no. 2, pp. 4507-4512. 
[5] J. Milton, Measuring Second Language Vocabulary Acquisitio. Clevedon, UK: Multilingual Matters Ltd, 2009.

[6] B. Dóczi and J. Kormos, Longitudinal Developments in Vocabulary Knowledge and Lexical Organization. 2015.

[7] E. Ostertagová and O. Ostertag, "Methodology and Application of Oneway ANOVA," Am. J. Mech. Eng., vol. 1, no. 7, pp. 256-261, 2013.

[8] J. Kirriemuir and A. McFarlane, "Literature Review in Games and learning," Futur. Ser., no. 8, p. 39, 2004.

[9] B. H. Sørensen and B. Meyer, "Serious Games in language learning and teaching - A theoretical perspective," DiGRA '07 - Proc. 2007 DiGRA Int. Conf. Situated Play, vol. 4, pp. 559-566, 2007.

[10] F. W. M. Yip and A. C. M. Kwan, "Online vocabulary games as a tool for teaching and learning English vocabulary," EMI. Educ. Media Int., vol. 43, no. 3, pp. 233-249, 2006. 